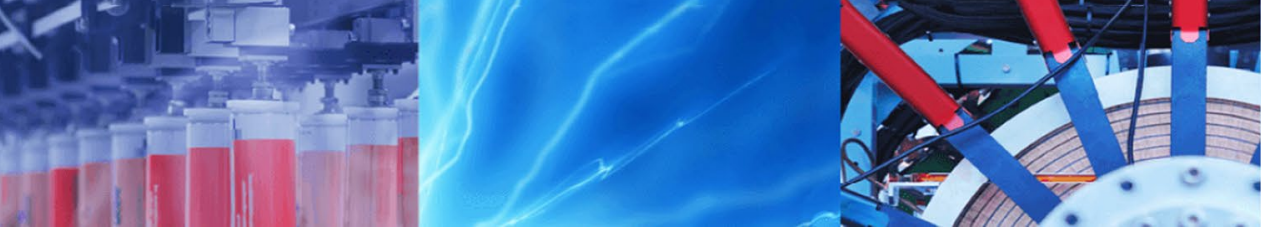

Research Article

\title{
Geochemical and environmental investigation of sewage-irrigated soils and crops of Sabzevar, NE of Iran
}

\author{
Seyed Ali Mazhari ${ }^{1}$ (D) Abbas Abhari ${ }^{2} \cdot$ Seyed Naser Mazhari ${ }^{1}$
}

(c) Springer Nature Switzerland AG 2019

\begin{abstract}
The present study identifies the effects of sewage irrigation on the surface soils geochemistry and the concentration of heavy metals in plants of Sabzevar area, which were irrigated for a long time by wastewater. This study shows that the sewage irrigation has led to decreasing $\mathrm{pH}$ and increasing organic matter, and also it makes the accumulation of $\mathrm{P}_{2} \mathrm{O}_{5}$, high-field-strength elements ( $\mathrm{Ga}, \mathrm{Ta}, \mathrm{Th}, \mathrm{U}$ and $\mathrm{Y}$ ) and heavy metals $(\mathrm{Cd}, \mathrm{Co}, \mathrm{Cu}, \mathrm{Pb}, \mathrm{Sn}$ and $\mathrm{Zn}$ ) in contaminated soils. Likewise, the concentration of rare-earth elements (REE) in contaminated soils is more than background samples with moderate enrichment of light REE compared with high REE in REE pattern diagram (mean $\mathrm{La}_{N} / \mathrm{Lu}_{N}=5.77$ ). The calculated transfer factor and enrichment factor indexes in plants grown on the polluted soils are significantly higher than the control samples which show the heavy metal enrichment in the contaminated samples. Although the cultivated crops on this area (maize, beet, alfalfa, barely) are used only for animal feed, the heavy metal analysis indicated that the concentration of $\mathrm{Cr}, \mathrm{Cu}, \mathrm{Ni}$ and $\mathrm{Pb}$ in these plants, especially alfalfa and maize, is more than the maximum permitted levels defined in different standards.
\end{abstract}

Keywords Soil · Sewage irrigation · Geochemistry $\cdot$ Sabzevar $\cdot$ Iran

\section{Introduction}

The use of municipal and industrial sewage for agricultural irrigation in urban and suburban areas is a common practice, especially in the regions with limited freshwater sources. This method of irrigation can provide a rich source of organic matter and beneficial nutrients for plants [9, 46]. However, wastewater may contain many heavy metals and toxic elements such as $\mathrm{As}, \mathrm{Cd}, \mathrm{Cr}, \mathrm{Co}, \mathrm{Ni}, \mathrm{Hg}, \mathrm{Pb}$ and $\mathrm{Zn}$. If sewage irrigation continues for a long time, excessive accumulation of toxic elements would lead to the contamination of soil and cultivated crops, which in turn has effects on the food chain quality and human health $[17,20,43]$.
The sewage irrigation of agricultural soils has been increasingly used in Iran to compensate for the shortage of groundwater supply and partially solve the problem of wastewater disposal. In recent years, many studies were focused on the different aspects of sewage irrigation on the soil composition and crop yields (e.g., $[16,18,44]$ ). Much of these studies impress on the harmful results of wastewater irrigation which caused high elevation of heavy metal concentrations in soils and plants of various regions in Iran [14, 42]. Recently, in order to avoid environmental hazards, the Iranian Development of Environment prohibited the sewage irrigation of many vegetation, fruits and human feed crops, while the cultivation of animal feed and non-edible plants is still allowed. The farmland area to the south of Sabzevar (NE of Iran) has been

Electronic supplementary material The online version of this article (https://doi.org/10.1007/s42452-019-1093-0) contains supplementary material, which is available to authorized users.

Seyed Ali Mazhari, ali54894@yahoo.com; s_mazhari@pnu.ac.ir| 'Department of Geology, Payame Noor University, Tehran 19395-4697, Iran. ${ }^{2}$ Department of Agronomy, Payame Noor University, Tehran 19395-4697, Iran.

SN Applied Sciences (2019) 1:1065 | https://doi.org/10.1007/s42452-019-1093-0

Received: 10 May 2019 / Accepted: 13 August 2019 / Published online: 21 August 2019 
Fig. 1 a The location of the studied area in the tectonic units of Iran (modified after Nabavi [34]). b A simple map illustrating lithological units of Sabzevar Range (modified from Rossetti et al. [39])
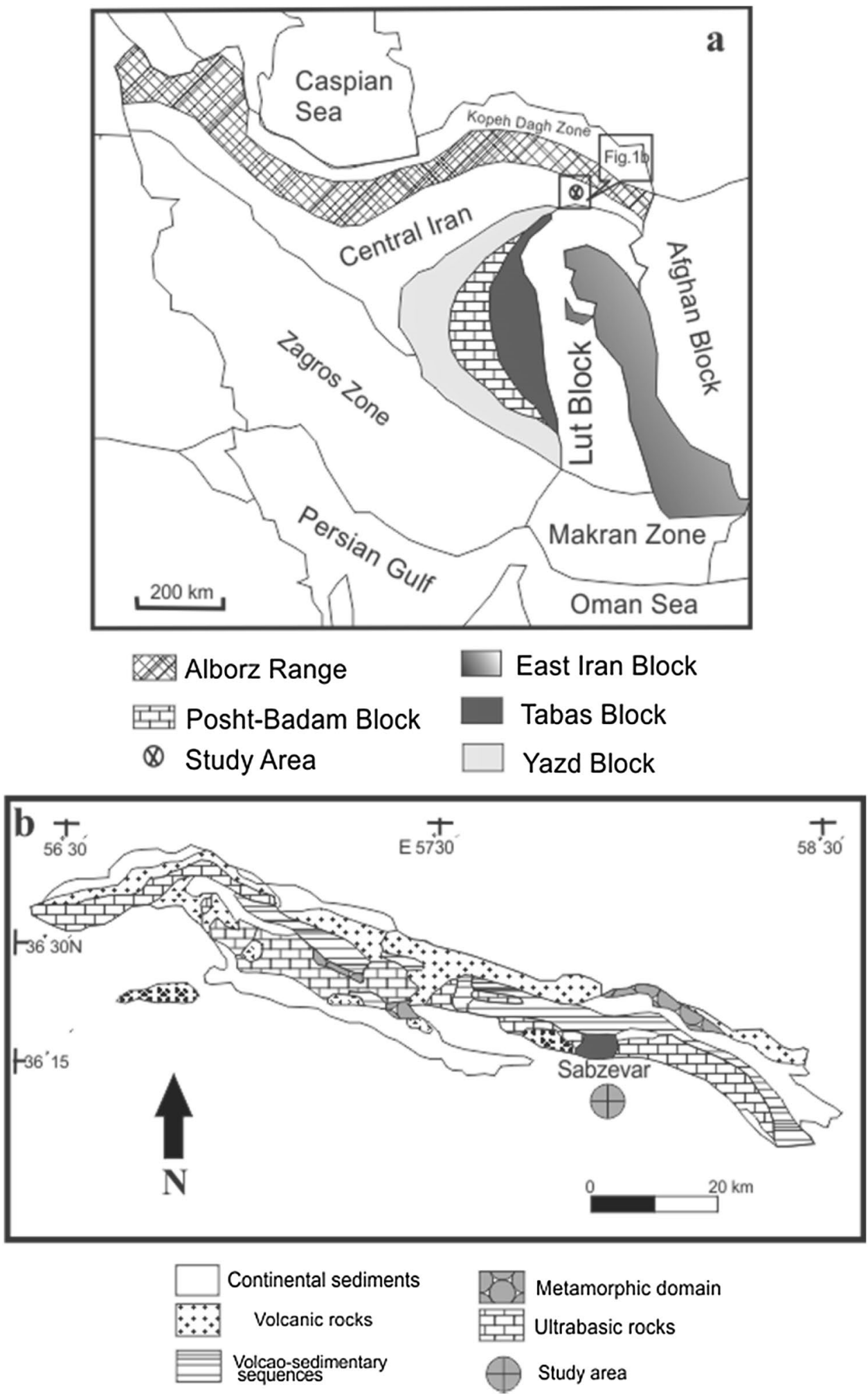

irrigated with wastewater for over 45 years. The cultivation of some plants such as beet, maize, alfalfa, barley, millet, sorghum (for animal feed) and cotton are permissible in the sewage-irrigated soils in this area. The regional soil composition and different relations between soil content and physicochemical parameters have been defined by previous studies (e.g., $[27,30])$. The primary goal of this study is to define the role of sewage irrigation to evoke geochemical variations in the surface soils. The next aim is the determination of heavy metal concentration in the 


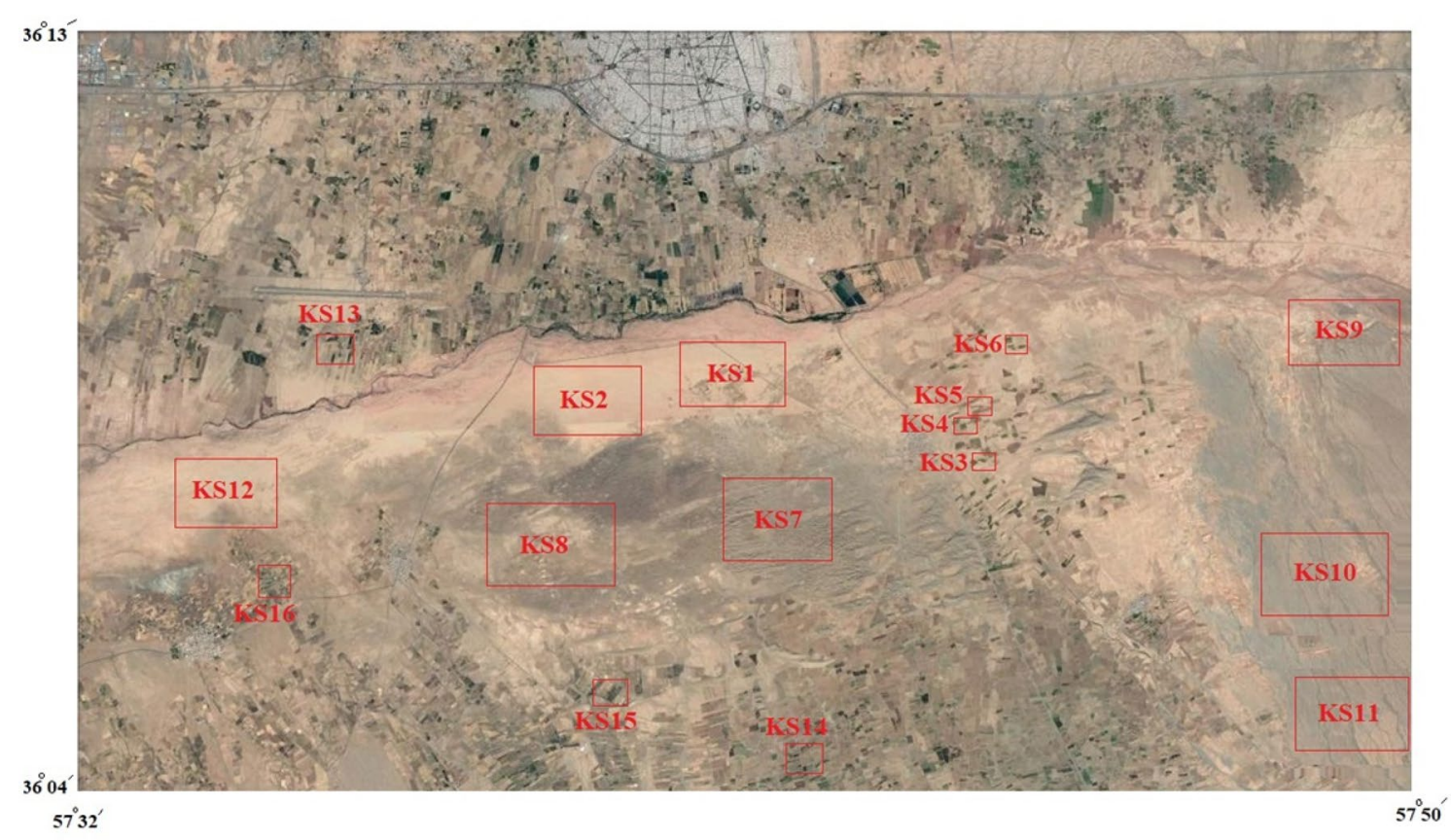

Fig. 2 The location of sampling sites in the studied area. KS1, KS2, KS7, KS8, KS9, KS10, KS11 and KS12 are the selected sites to determine background geochemistry of soils in this area. KS3 (maize farm), KS4 (alfalfa farm), KS5 (beet farm) and KS6 (barely farm) are

cultivated plants to monitor probable environmental hazards. The results of this study will be useful to constrain geochemical factors involving wastewater-polluted areas, and for local pollution control and management of wastewater consumption or treatment.

\section{Materials and methods}

\subsection{Geological background and sample selection}

The studied area is located to the south of Sabzevar town, NE of Iran. This area is a part of a geological unit titled Sabzevar Range (SR), which makes up the largest Iranian ophiolite mélange. The SR is situated in the Central Iran Microcontinent (Fig. 1a) and exhibits complex geological characteristics that include filed relations [41], structural complications [6], distinct metamorphic rocks [39] and extensive tectono-magmatic evolution [22, 33]. The Sabzevar ophiolite mélange is composed of all sections of ophiolitic sequences, but it is completely tectonized (Fig. 1b). This mélange is formed in the Late Cretaceous extensional events resulted by back-arc rifting of NeoTethys $[22,39]$. The ultramafic and serpentinitic rocks are the major occurrence of SR which are related to the ophiolite mélange (Fig. 1b). In addition to the ophiolitic assemblage, there are a large number of post-ophiolitic rocks in sewage-irrigated sites. KS13, KS14, KS15 and KS16 are maize, beet, alfalfa and barley farms which are the selected sites for well-irrigated soils

SR. These rocks appear as various plutonic, sub-volcanic and volcanic bodies, and many of them have adakitic properties $[3,19,29,40]$.

The studied area has even topography and is covered by alluvium deposits from northern ophiolitic melange (Fig. 1b). The soils of this area are mostly immature cambisols derived from weathering of those deposits. In this study, the surface soils (5-20 cm depth) were sampled with a stainless-steel hand trowel. The top-level soil $(0-5 \mathrm{~cm})$ was removed due to the presence of abundant waste and transported components. Sixteen sites were selected for sampling which includes four sewage-irrigated farms (as polluted soils), four well-irrigated farms (as non-polluted agricultural soils) and eight sites from not-irrigated soils of this region (as background samples). The two last groups are used as control samples to evaluate different geochemical and environmental changes induced by wastewater pollution. The location of sampling sites is shown in Fig. 2. At each sampling site, a mixed sample (near $3 \mathrm{~kg}$ ) was collected by the integration of five subsamples. These subsamples were collected from four corners and the center of each sampling site regardless of the size area of the sampling site. The soil samples were air-dried and sieved to $<2 \mathrm{~mm}$ for further analyses.

The selected farms for background sites had the same agronomic practice including NPK $(150 \mathrm{~kg} \mathrm{~N}, 30 \mathrm{~kg} \mathrm{P}$, $60 \mathrm{~kg} \mathrm{~K})+$ manure fertilization (1 Mg dry weight solid cattle 
Table 1 Physicochemical properties of studied soils

\begin{tabular}{llllllll}
\hline Sample no. & ID & pH & TOC & CEC & Sand & Silt & Clay \\
\hline KS1 & NN & 7.73 & 0.537 & 13.53 & 54 & 36 & 10 \\
KS2 & NN & 7.85 & 0.504 & 14.22 & 42 & 47 & 11 \\
KS7 & NN & 7.79 & 0.435 & 13.83 & 45 & 43 & 12 \\
KS8 & NN & 7.78 & 0.48 & 13.44 & 46 & 39 & 15 \\
KS9 & NN & 7.75 & 0.51 & 13.23 & 47 & 39 & 14 \\
KS10 & NN & 7.95 & 0.446 & 12.95 & 46 & 42 & 12 \\
KS11 & NN & 7.69 & 0.559 & 13.7 & 48 & 40 & 12 \\
KS12 & NN & 7.86 & 0.473 & 13.62 & 49 & 38 & 13 \\
KS3 & PA & 7.16 & 1.763 & 15.1 & 35 & 40 & 25 \\
KS4 & PA & 7.08 & 2.034 & 14.79 & 32 & 42 & 26 \\
KS5 & PA & 7.11 & 1.985 & 15.37 & 34 & 41 & 25 \\
KS6 & PA & 7.13 & 1.868 & 15.46 & 33 & 43 & 24 \\
KS13 & NA & 7.52 & 0.98 & 14.58 & 34 & 41 & 25 \\
KS14 & NA & 7.36 & 0.955 & 14.8 & 35 & 42 & 23 \\
KS15 & NA & 7.48 & 1.025 & 14.65 & 36 & 41 & 23 \\
KS16 & NA & 7.44 & 0.926 & 14.47 & 33 & 42 & 25 \\
Mean & NN & 7.80 & 0.49 & 13.57 & 47.13 & 40.50 & 12.38 \\
SD & NN & 0.08 & 0.04 & 0.38 & 3.48 & 3.42 & 1.60 \\
Mean & PA & 7.12 & 1.91 & 15.18 & 33.50 & 41.50 & 25.00 \\
SD & PA & 0.03 & 0.12 & 0.30 & 1.29 & 1.29 & 0.82 \\
Mean & NA & 7.45 & 0.97 & 14.63 & 34.50 & 41.50 & 24.00 \\
SD & NA & 0.07 & 0.04 & 0.14 & 1.29 & 0.58 & 1.15 \\
$p$ values & & $3 \mathrm{E}-09$ & $2 \mathrm{E}-13$ & $4 \mathrm{E}-06$ & $1 \mathrm{E}-06$ & 0.749 & $7 \mathrm{E}-10$ \\
\hline
\end{tabular}

$N A$ non-polluted agricultural soils, NN background samples (non-agricultural non-polluted soils), PA sewage-irrigated soils (polluted soils) manure $\mathrm{ha}^{-1}$ year $\left.^{-1}\right)$. The sampling of all plants was done in September 2016. The plant samples were collected from the same area where the soil samples were gathered. In both polluted and non-polluted farms, eight plant samples were collected from edible portions of maize (grains), barely (grains), beet and alfalfa. For every plant, one sample was selected from sewage-irrigated soils (as polluted samples) and another sample was collected from wellirrigated soils (as control samples). The location and analyzed plant of each farm are described in the Fig. 2 caption. For clearing soil and other particles which adhere to the plant, we do the following steps. First, all samples were cleaned by tap water. Next, they were washed three times with deionized water. Then, the excess water was removed from samples with blotting paper, and then, samples were cut into small pieces. Finally, every sample was packed into a single bag and dried to $40^{\circ} \mathrm{C}$ in an oven.

\subsection{Analyses}

The soil $\mathrm{pH}$ was measured in a 1:2.5 ratio of soil/solution (a solution of water and $1 \mathrm{M} \mathrm{KCl}$ ) with a glass electrode $\mathrm{pH}$ meter. For measuring the total organic carbon content
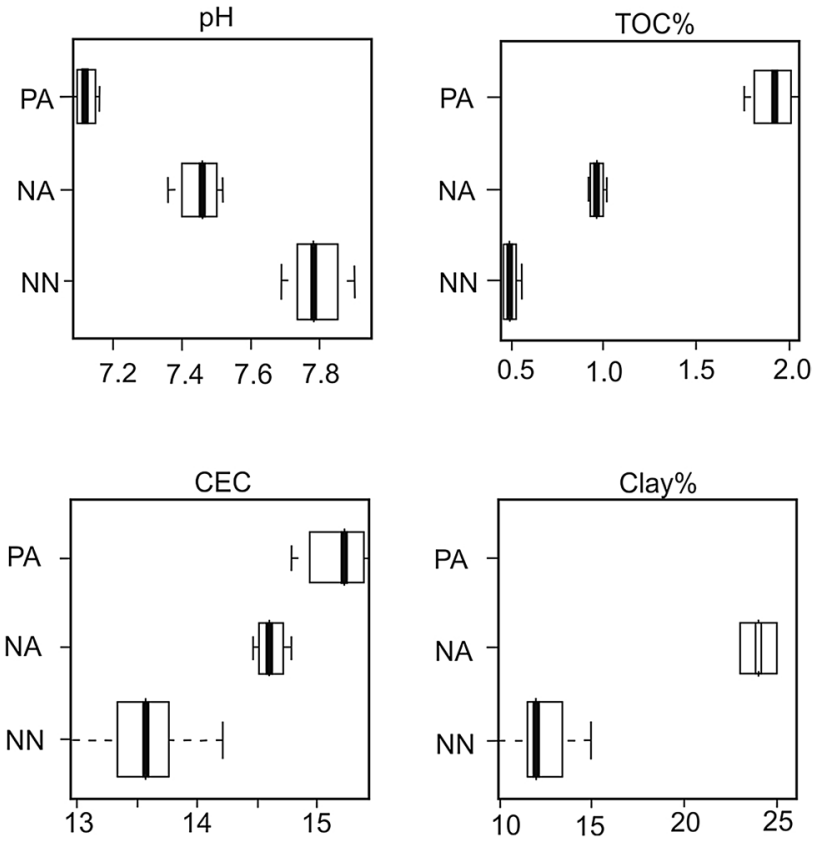

Fig. 3 The physicochemical differences (mean values) among various soils in the study area. $\mathrm{NN}=$ background samples, $\mathrm{PA}=$ sewageirrigated soils, $N A=$ non-polluted agricultural samples 

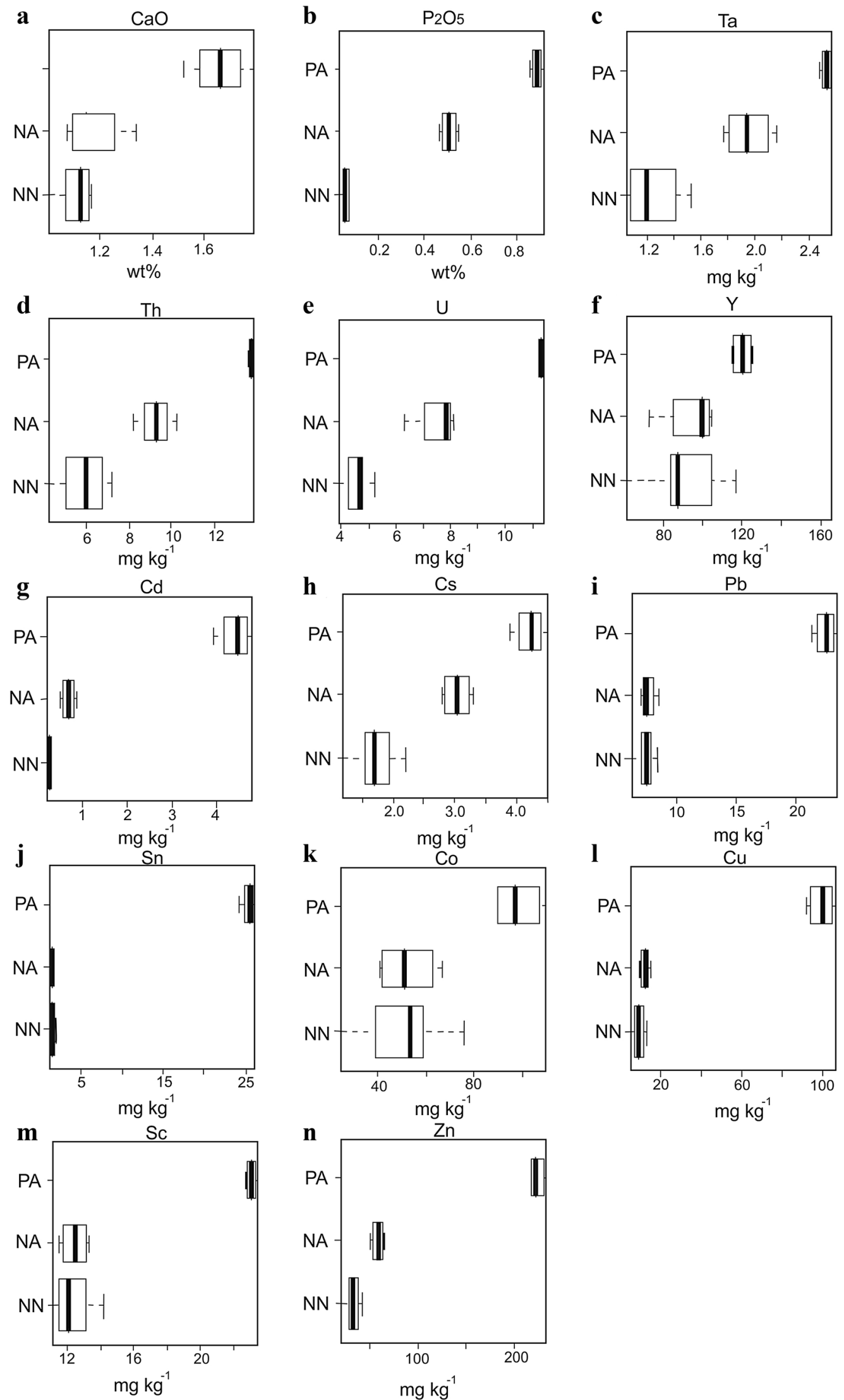

Fig. 4 Major oxides (wt\%) and trace element $\left(\mathrm{mg} \mathrm{kg}^{-1}\right)$ concentrations (mean values) of different soil samples. Abbreviations are given in Fig. 3 

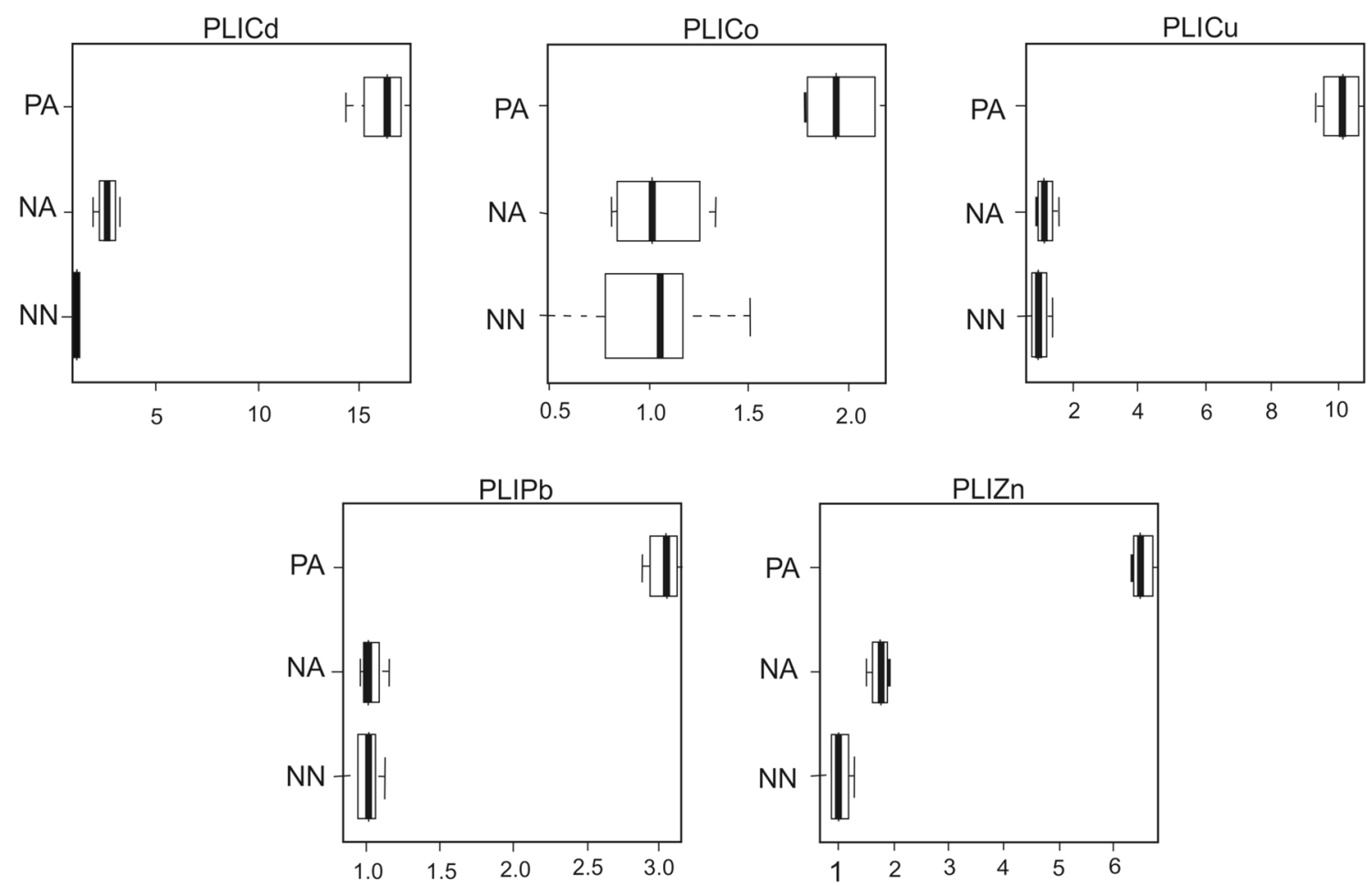

Fig. 5 The calculated average of pollution load index (PLI) in various soil samples. Abbreviations are given in Fig. 3

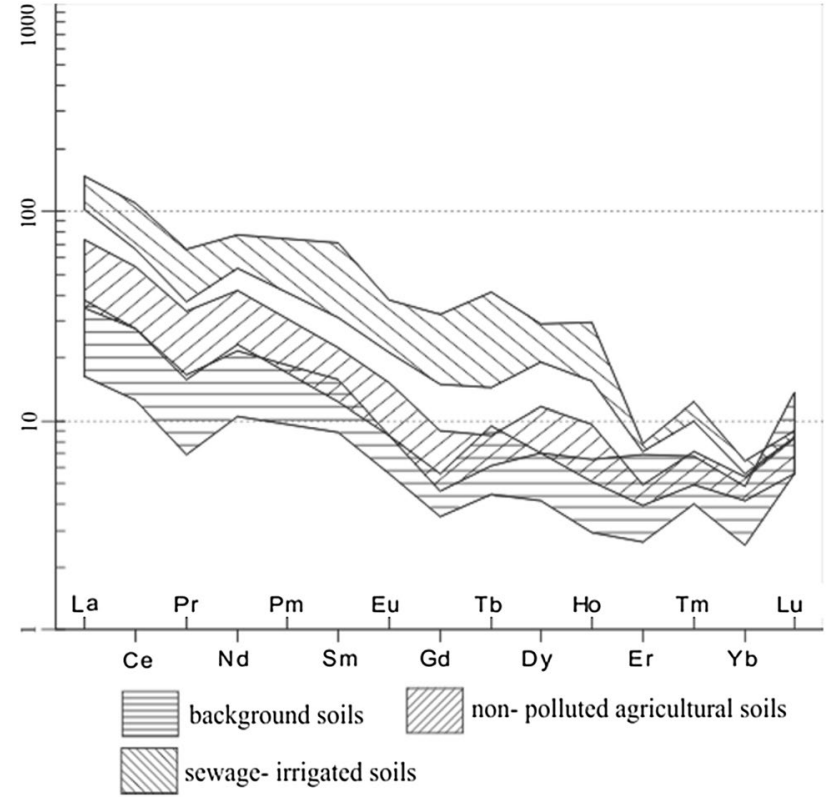

Fig. 6 Chondrite-normalized REE plot of soil samples (normalization values from Sun and McDonough [45])

(TOC) and the cation exchange capacity (CEC), the modified wet oxidation method (Walkley-Black) and Bower and Hatcher procedure [7] were used, respectively. In order to obtain the size distribution of soil samples, granulometric analysis was carried out by sieving (sand) and sedimentation and extraction with a Robinson pipette (clay and silt), and the size fractions were classified as clay $(<0.002 \mathrm{~mm})$, silt (0.002-0.05) and sand (0.05-2 mm).

To perform chemical analyses, soil samples were ground to a fine powder $(<200 \mathrm{~nm})$. Major oxides were determined by XRF after fusion with lithium tetraborate. Typical precision was better than $\pm 1.5 \%$ for an analyte concentration of $10 \mathrm{wt} \%$. The powdered soils were digested by a strong multi-acid method: $0.25 \mathrm{gm}$ of each sample was heated by a mixture of $\mathrm{HNO}_{3}-\mathrm{HClO}_{4}$ - $\mathrm{HF}$ acids, and the residual fraction was dissolved in $\mathrm{HCl}$ to represent the total concentration of elements. Then, the trace element concentrations were analyzed by ICP-MS. The XRF and ICP-MS analyses were performed in Actlabs laboratory, Canada, by Dolan et al.'s [13] methodology. Detection of limits of these analyzes is presented in the last rows of supplementary Table 1. Since the detection limit was not applicable for some heavy metals in ICP-MS results (Table 1, supplementary), the concentrations of $\mathrm{Cd}, \mathrm{Co}, \mathrm{Cr}, \mathrm{Cu}, \mathrm{Ni}, \mathrm{Pb}$ and $\mathrm{Zn}$ were analyzed by flame atomic absorption spectrometer (Varian AA240) in Abram Institute, Iran.

The bioavailable content of heavy metals in surface soils was determined by DTPA (diethylene triamine pentaacetic acid) extraction using the method of Lindsay and Norwell [26]. In this method, a buffered solution of $20 \mathrm{~mL}$ of a 0.005-M DTPA, $0.01 \mathrm{M} \mathrm{CaCl}_{2}$ and $0.1 \mathrm{M}$ triethanolamine 
Table 2 The heavy metal concentration $\left(\mathrm{mg} \mathrm{kg}^{-1}\right)$ of soil samples resulted from DTPA extraction

\begin{tabular}{lllllllll}
\hline Sample no. & ID & $\mathrm{Cd}$ & $\mathrm{Co}$ & $\mathrm{Cr}$ & $\mathrm{Cu}$ & $\mathrm{Ni}$ & $\mathrm{Pb}$ & $\mathrm{Zn}$ \\
\hline KS1 & $\mathrm{NN}$ & 0.04 & 10.3 & 6.25 & 2.03 & 65.53 & 1.25 & 8.85 \\
KS2 & $\mathrm{NN}$ & 0.04 & 6.57 & 4.49 & 1.29 & 62.51 & 1.58 & 8.13 \\
KS7 & $\mathrm{NN}$ & 0.05 & 4.92 & 3.02 & 2.35 & 66.24 & 1.39 & 9.72 \\
KS8 & $\mathrm{NN}$ & 0.03 & 10.45 & 4.01 & 1.2 & 66.15 & 1.6 & 6.35 \\
KS9 & $\mathrm{NN}$ & 0.04 & 14.81 & 5.83 & 1.66 & 73.7 & 1.42 & 12.08 \\
KS10 & $\mathrm{NN}$ & 0.04 & 9.16 & 4.47 & 2.29 & 62.38 & 1.48 & 11.85 \\
KS11 & $\mathrm{NN}$ & 0.05 & 10.78 & 4.2 & 2.73 & 74.2 & 1.63 & 10.19 \\
KS12 & $\mathrm{NN}$ & 0.04 & 12.84 & 4.13 & 1.86 & 65.59 & 1.5 & 9.04 \\
KS3 & $\mathrm{PA}$ & 2.48 & 34.29 & 23.44 & 34.18 & 203.19 & 13.47 & 111.23 \\
KS4 & $\mathrm{PA}$ & 2.26 & 27.92 & 23.61 & 39.87 & 205.56 & 12.58 & 114.8 \\
KS5 & $\mathrm{PA}$ & 2.55 & 35.16 & 24.26 & 38.6 & 201.69 & 13.1 & 119.29 \\
KS6 & $\mathrm{PA}$ & 2.47 & 27.96 & 23.7 & 35.72 & 206.3 & 13.57 & 108.12 \\
KS13 & $\mathrm{NA}$ & 0.13 & 13.51 & 8.49 & 3.97 & 61.13 & 2.15 & 18.51 \\
KS14 & $\mathrm{NA}$ & 0.22 & 8.73 & 7.25 & 3.18 & 75.05 & 1.81 & 22.67 \\
KS15 & $\mathrm{NA}$ & 0.18 & 8.14 & 5.16 & 2.32 & 6.37 & 1.88 & 23.72 \\
KS16 & $\mathrm{NA}$ & 0.2 & 11.65 & 6.33 & 2.49 & 73.86 & 1.92 & 21.66 \\
Mean & $\mathrm{NN}$ & 0.04 & 9.98 & 4.55 & 1.93 & 67.04 & 1.48 & 9.53 \\
SD & NN & 0.01 & 3.17 & 1.03 & 0.53 & 4.53 & 0.13 & 1.89 \\
Mean & $\mathrm{PA}$ & 2.44 & 31.33 & 23.75 & 37.09 & 204.19 & 13.18 & 113.36 \\
SD & $\mathrm{PA}$ & 0.13 & 3.93 & 0.36 & 2.60 & 2.13 & 0.45 & 4.80 \\
Mean & $\mathrm{NA}$ & 0.18 & 10.51 & 6.81 & 2.99 & 54.10 & 1.94 & 21.64 \\
SD & $\mathrm{NA}$ & 0.04 & 2.52 & 1.41 & 0.75 & 32.44 & 0.15 & 2.25 \\
$p$ values & & $5 \mathrm{E}-17$ & $2 \mathrm{E}-07$ & $6 \mathrm{E}-13$ & $6 \mathrm{E}-15$ & $4 \mathrm{E}-09$ & $2 \mathrm{E}-18$ & $1 \mathrm{E}-16$ \\
\hline & & & & & & & &
\end{tabular}

was used to dissolve $10 \mathrm{~g}$ of soil sample for $2 \mathrm{~h}$. Then, the contents were filtrated and analyzed for $\mathrm{Cd}, \mathrm{Co}, \mathrm{Cr}, \mathrm{Cu}, \mathrm{Ni}$, $\mathrm{Pb}$ and $\mathrm{Zn}$ by flame atomic absorption spectrometer. The analysis of BCR-100 standard showed that the precision of resulted data was $\pm 5 \%$. The dried plant samples were ground in a stainless-steel mill and digested in a mixture of distilled $\mathrm{HNO}_{3}$ and $\mathrm{HClO}_{4}$ (in the ratio of 3:1); and the heavy metal concentrations were analyzed by atomic absorption spectrometer.

All the statistics were performed by means of the SPSS version 17.0 software for Windows. Data from the different chemical measurements were subjected to one-way analysis of variance (ANOVA). The statistically significant difference was set at $5 \%$. Mean values obtained for the variables studied in the different groups were compared by one-way ANOVA (Duncan's multiple ranges) assuming that there were significant differences among them when the statistical comparison gave $p<0.05$.

\subsection{Evaluation of pollution and quality indexes}

A modified pollution load index (PLI) was calculated as the following equation to evaluate heavy soil contamination by sewage irrigation [48].

$\mathrm{PLI}=C_{\text {soil }} / C_{\text {reference }}$
$C_{\text {soil }}$ and $C_{\text {reference }}$ are the concentrations of heavy metal in the contaminated and background samples, respectively. The mean values of non-polluted non-agricultural samples (NN samples of supplementary Table 1) were used as the background concentration for each element.

The transfer factor (TF) was calculated by dividing the concentration of an element in a plant by the total element concentration in the soil [48].

Further to investigate the role of sewage irrigation on the plant composition, enrichment factor (EF) was calculated using the following equation [8]:

$\mathrm{EF}=$ [concentration of metal in a plant grown on the polluted soil/concentration of metal in polluted soil]/ [concentration of metal in a plant grown on control soil/ concentration of metal in control soil].

\section{Results and discussion}

\subsection{Physicochemical parameters}

The physicochemical properties of soil samples show systematic variations between polluted, non-polluted agricultural and background soils (Table 1). The polluted samples have the highest values of TOC (1.7-2.03\%, 

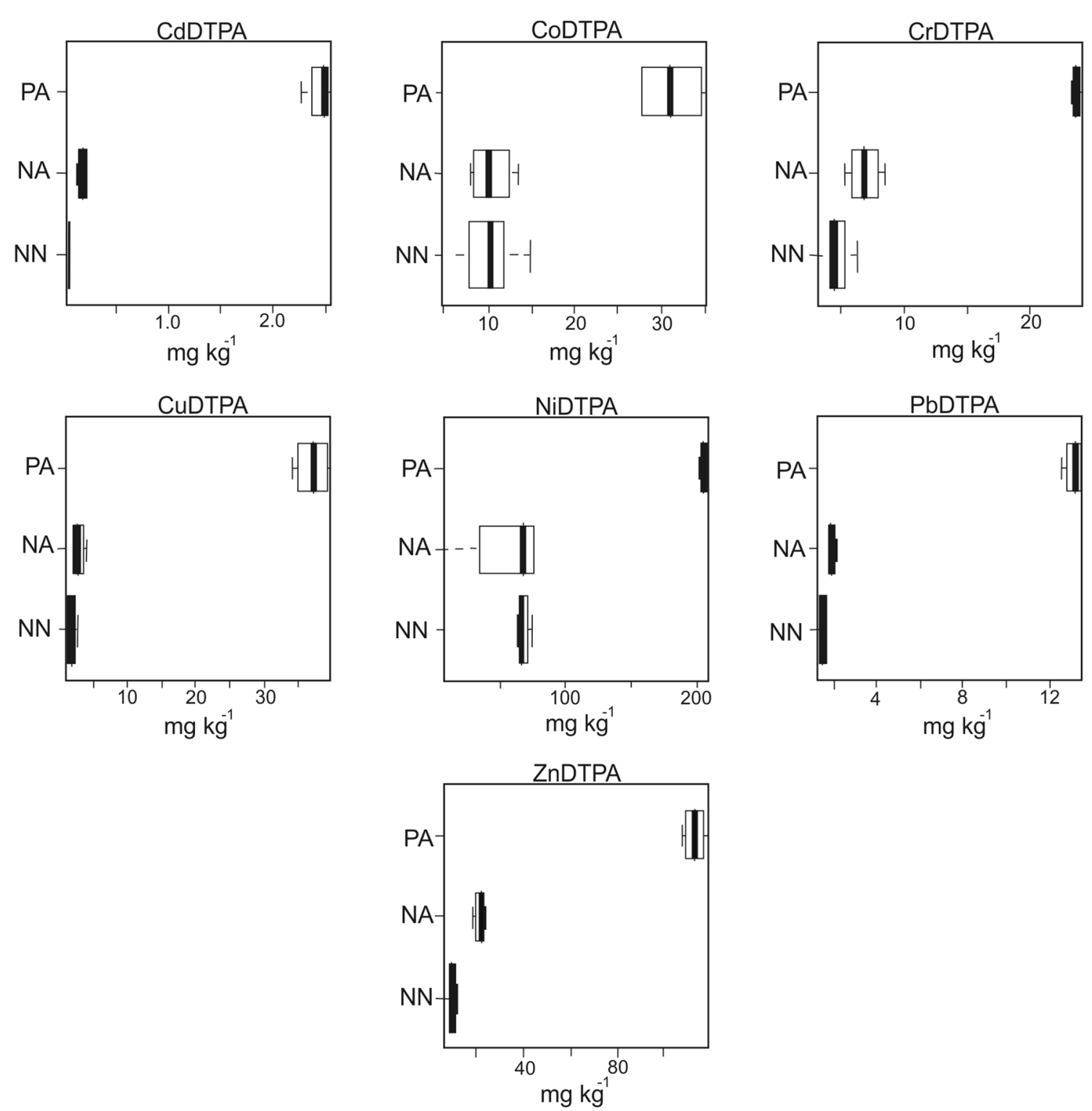

Fig. 7 The mean values of DTPA extraction of heavy metals in the studied soils. Abbreviations are given in Fig. 3

mean $1.91 \pm 0.12)$, CEC (14.79-15.48, mean $15.18 \pm 0.30$ $\mathrm{cmol}(+) / \mathrm{kg})$ and clay content $(24-26 \%$, mean $25 \% \pm 1)$ while $\mathrm{pH}$ measurements in these soils $(7.08-7.16$, mean $7.12 \pm 0.03)$ are lower than other samples. In other side, background samples are distinguished by high $\mathrm{pH}$ (7.69-7.95, mean 7.80 \pm 0.08$)$ and low TOC $(0.43-0.56 \%$, mean $0.49 \% \pm 0.04)$, CEC (12.95-14.72, mean $13.57 \pm 0.38$ $\mathrm{cmol}(+) / \mathrm{kg})$ and clay content $(10-15 \%$, mean $12 \% \pm 2)$; non-polluted agricultural soils have intermediate quantities of these parameters (Table 1 and Fig. 3).

The $\mathrm{pH}$ is a key parameter in controlling the metal mobility and availability (e.g., [32]), and most of the metals tend to be available at lower acidity [37]. The organic content of the soil is another important factor that positively relates to the heavy metal quantities [24]. Many studies indicate that wastewater irrigation results in addition to TOC in soil (e.g., [10, 23]). In the studied area, long-time sewage irrigation decreased soil pH (7.1 vs. 7.8 ) and increased dissolved organic carbon (1.9 vs $0.5 \%$ ) compared to background soils, which could enhance the phyto-availability of heavy metals. Other chemical data approved this assumption which will be discussed in the next sections. Agricultural activity has increased clay content of the studied soils that is a common characteristic of the agricultural soils in the Sabzevar area $[29,30]$.

\subsection{Soils geochemical composition}

The geochemical compositions of the studied soils are presented in supplementary Table 1. All samples show similar 
Table 3 The calculated bioavailability (\%) of heavy metals in the studied soil samples

\begin{tabular}{lllllllll}
\hline Sample no. & ID & $\mathrm{Cd}$ & $\mathrm{Co}$ & $\mathrm{Cr}$ & $\mathrm{Cu}$ & $\mathrm{Ni}$ & $\mathrm{Pb}$ & $\mathrm{Zn}$ \\
\hline KS1 & $\mathrm{NN}$ & 16.00 & 19.01 & 0.50 & 20.14 & 9.02 & 20.13 & 28.06 \\
KS2 & $\mathrm{NN}$ & 14.29 & 20.81 & 0.50 & 18.70 & 9.69 & 20.82 & 28.10 \\
KS7 & $\mathrm{NN}$ & 16.13 & 19.74 & 0.37 & 19.29 & 10.03 & 19.39 & 27.39 \\
KS8 & $\mathrm{NN}$ & 13.64 & 20.05 & 0.51 & 20.30 & 9.40 & 19.16 & 28.22 \\
KS9 & $\mathrm{NN}$ & 13.79 & 19.53 & 0.52 & 19.26 & 9.81 & 20.76 & 27.61 \\
KS10 & $\mathrm{NN}$ & 14.29 & 19.62 & 0.46 & 18.42 & 10.06 & 19.84 & 28.03 \\
KS11 & $\mathrm{NN}$ & 16.67 & 19.93 & 0.60 & 19.93 & 10.42 & 20.12 & 27.84 \\
KS12 & $\mathrm{NN}$ & 15.38 & 20.30 & 0.51 & 20.35 & 9.98 & 19.95 & 28.38 \\
KS3 & $\mathrm{PA}$ & 54.39 & 32.86 & 2.51 & 37.07 & 25.01 & 58.95 & 50.92 \\
KS4 & $\mathrm{PA}$ & 57.36 & 31.08 & 2.49 & 37.35 & 25.10 & 58.98 & 50.95 \\
KS5 & $\mathrm{PA}$ & 52.90 & 31.81 & 2.51 & 37.42 & 25.06 & 58.82 & 51.15 \\
KS6 & $\mathrm{PA}$ & 55.76 & 31.01 & 2.58 & 36.91 & 24.97 & 57.99 & 49.88 \\
KS13 & NA & 25.49 & 20.16 & 0.82 & 25.40 & 10.03 & 25.21 & 36.03 \\
KS14 & NA & 25.29 & 20.17 & 0.72 & 25.75 & 9.96 & 25.56 & 36.25 \\
KS15 & NA & 27.69 & 19.90 & 0.62 & 17.60 & 0.92 & 25.34 & 36.10 \\
KS16 & NA & 27.03 & 19.69 & 0.69 & 24.83 & 10.20 & 25.40 & 36.74 \\
Mean & NN & 15.02 & 19.87 & 0.50 & 19.55 & 9.80 & 20.02 & 27.95 \\
SD & NN & 1.17 & 0.54 & 0.06 & 0.74 & 0.43 & 0.58 & 0.33 \\
Mean & PA & 55.10 & 31.69 & 2.52 & 37.19 & 25.03 & 58.69 & 50.73 \\
SD & PA & 1.90 & 0.86 & 0.04 & 0.24 & 0.06 & 0.47 & 0.57 \\
Mean & NA & 26.37 & 19.98 & 0.71 & 23.39 & 7.78 & 25.38 & 36.28 \\
SD & NA & 1.17 & 0.23 & 0.08 & 3.88 & 4.58 & 0.15 & 0.32 \\
$p$ values & & $3 \mathrm{E}-15$ & $1 \mathrm{E}-13$ & $7 \mathrm{E}-16$ & $7 \mathrm{E}-09$ & $6 \mathrm{E}-08$ & $5 \mathrm{E}-21$ & $4 \mathrm{E}-19$ \\
\hline
\end{tabular}

content in major oxides of $\mathrm{SiO}_{2}, \mathrm{TiO}_{2}, \mathrm{Al}_{2} \mathrm{O}_{3}, \mathrm{FeO}_{\mathrm{t}}, \mathrm{MgO}$, $\mathrm{K}_{2} \mathrm{O}$ and $\mathrm{Na}_{2} \mathrm{O}$. The concentration of $\mathrm{CaO}$ in polluted soils is slightly higher than that in the other samples; but $\mathrm{P}_{2} \mathrm{O}_{5}$ concentration in background samples (0.04-0.08 wt\%) is much less than that in non-polluted agricultural (0.47-0.53 wt\%) and polluted (0.86-0.92 wt\%) soils (Fig. 4a, b).

The three different groups of selected soils display distinct trace element contents. In comparison with other samples, the polluted surface soils show a generally higher concentration of many high-field-strength elements (HFSE) such as Ga, Ta, Th, $U$ and $Y$ (supplementary Table 1; Fig. 4c-f). In particular, these soils are enriched in heavy metals of $\mathrm{Cd}, \mathrm{Co}, \mathrm{Cu}, \mathrm{Pb}, \mathrm{Sn}$ and $\mathrm{Zn}$ (Fig. $4 \mathrm{~g}-\mathrm{n}$ ).

The PLI values emphasize on the high enrichment of $C d$, $\mathrm{Cu}, \mathrm{Zn}, \mathrm{Pb}$ and $\mathrm{Co}$ in the contaminated soils (Fig. 5). The enrichment of these metals in soils could result in different fertilizers or wastewater irrigation [1,38]. As it is shown in supplementary Table 1 and Fig. 5, the non-polluted agricultural soils of SR have slightly higher heavy metal concentration than background which could be ascribed to phosphatic fertilizer, but severe metal enrichment of polluted samples (Fig. 5) is originated from sewage irrigation.

All samples have a high concentration of $\mathrm{Ni}$ (620-826 $\mathrm{mg} \mathrm{kg}^{-1}$ ) and $\mathrm{Cr}\left(695-1035 \mathrm{mg} \mathrm{kg}^{-1}\right)$, and there is no the obvious difference between polluted and other soils content (supplementary Table 1). However, the total concentration of $\mathrm{Ni}$ and $\mathrm{Cr}$ could not be indicator of sewage-irrigation pollution in SR soils because not only the existence of high total concentration of $\mathrm{Cr}$ and $\mathrm{Ni}$ is an evident geochemical characteristic of serpentinitic and ultramafic-derived soils [4] but also SR soils normally have high concentration of these elements [30].

The use of rare-earth elements (REE) in soil investigations has been increasingly developed in recent years. The REE could be an appropriate indicator to define pedogenetic processes, weathering condition and source identification of soils $[12,25]$. The REE composition of SR surface soils is significantly dependent on parent materials $[28,31]$. So, the investigation of sewage irrigation on REE content could be helpful to determine soil geochemical variations in this area. In the studied area, background samples have relatively low REE concentrations (mean $\sum \mathrm{REE}=40.73 \mathrm{mg} \mathrm{kg}^{-1}$ ) with moderate enrichment of light REE (LREE) compared with heavy REE (HREE) in REE pattern diagram (mean $\mathrm{La}_{N} / \mathrm{Lu}_{N}=5.77$; Fig. 6). The REE concentration increases in non-polluted agricultural soils (mean $\Sigma$ REE $=90.13 \mathrm{mg} \mathrm{kg}^{-1}$; mean $\mathrm{La}_{N} / \mathrm{Lu}_{N}=12.45$ ); and polluted samples show the highest REE quantities (mean $\sum R E E=180.44 \mathrm{mg} \mathrm{kg}^{-1}$ ) with intense enrichment of LREE/ HREE (mean $\mathrm{La}_{N} / \mathrm{Lu}_{N}=20.31$; Fig. 6). These results suggest that increasing REE concentration and enhancing LREE/ 


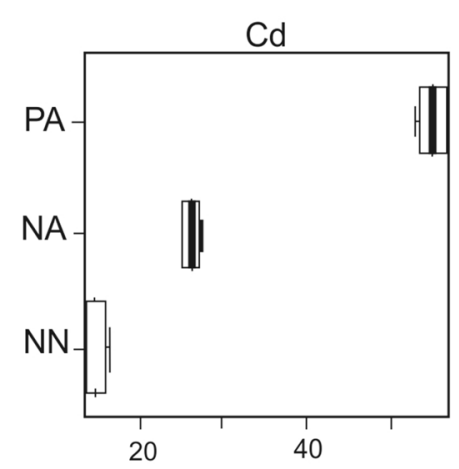

\section{Bioavailability (\%)}
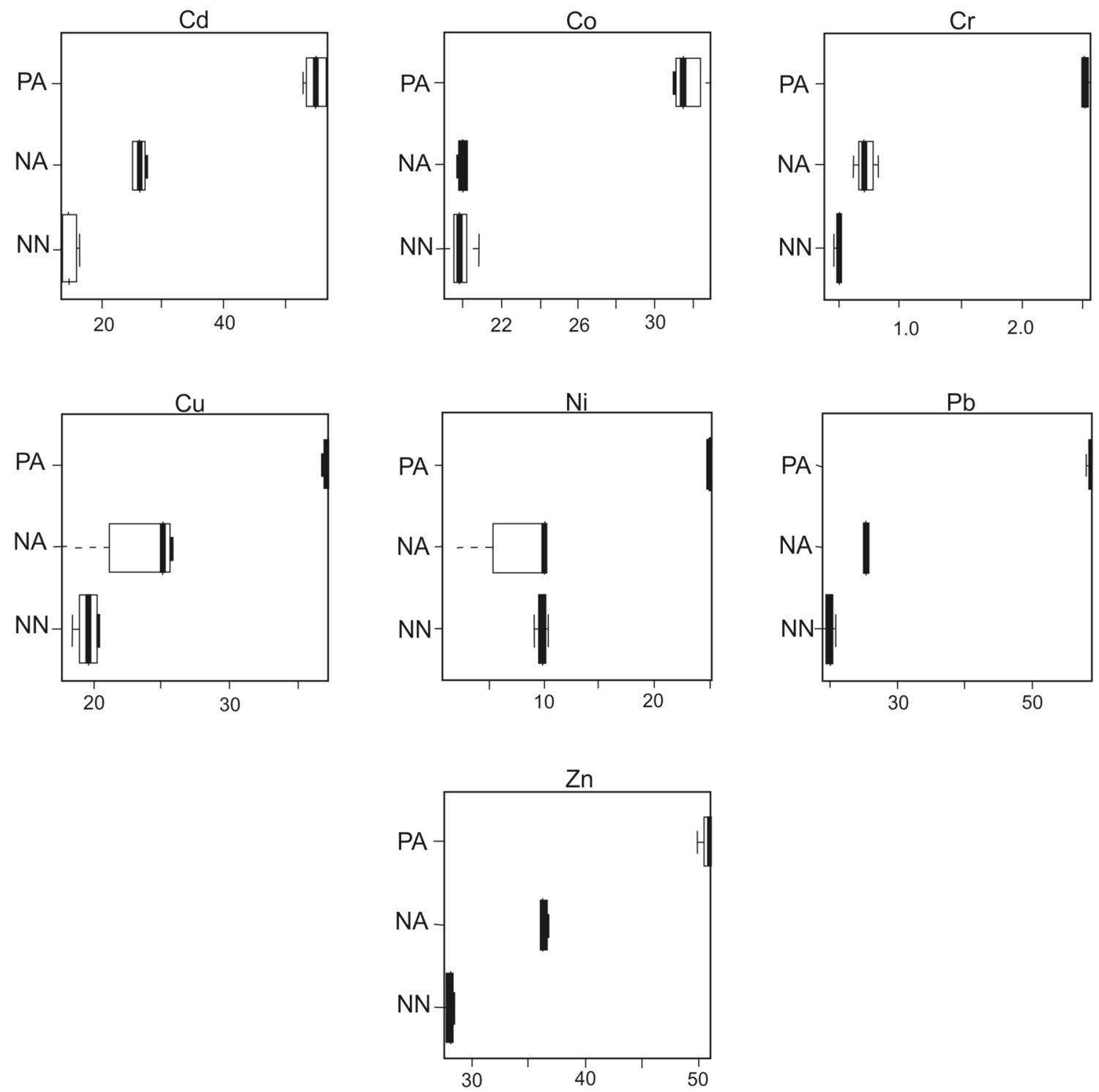

Fig. 8 The bioavailability (\%) comparison of different soil samples. Abbreviations are given in Fig. 3

HREE are the consequences of agricultural activities and wastewater irrigation in the surface soils of SR.

\subsection{Soil bioavailability}

The DTPA extraction method provides a suitable proxy for evaluating heavy metal bioavailability of plants in soils and soil solutions, especially in serpentine and ultramaficderived soils [21, 35]. The results of DTPA extraction for soil samples are shown in Table 2. The polluted soils have the highest concentration of heavy metals in DTPA extraction (Fig. 7). In this regard, $\mathrm{Ni}$ and $\mathrm{Zn}$ demonstrate higher values, while $\mathrm{Cd}$ and $\mathrm{Pb}$ release lower concentrations
(Table 2). However, the order of extractable content is not the same in all samples, so that some background soils (KS1, KS8, KS9 and KS11 samples) have higher extractable Co than Zn (Table 2).

In the environmental investigation of soil chemistry, the detecting bioavailable capabilities of soil samples are a crucial issue. Here, the bioavailability is defined as DTPAextractable percent value divided by total concentration. The bioavailability values order in the studied soils is completely different from DTPA extraction, and there are various trends among polluted, background and non-polluted agricultural samples (Table 3). $\mathrm{Cr}$ and $\mathrm{Ni}$ show the lowest bioavailability in all soils. Chromium should be considered 
Table 4 The heavy metals concentration $\left(\mathrm{mg} \mathrm{kg}^{-1}\right)$ of plants

\begin{tabular}{|c|c|c|c|c|c|c|c|c|c|}
\hline Sample no. & ID & Plant & $\mathrm{Cd}$ & Co & $\mathrm{Cr}$ & $\mathrm{Cu}$ & $\mathrm{Ni}$ & $\mathrm{Pb}$ & $\mathrm{Zn}$ \\
\hline KS3 & CS & Maize & 0.12 & 2.86 & 10.35 & 39.83 & 112.79 & 5.69 & 78.46 \\
\hline KS5 & CS & Beet & 0.19 & 2.16 & 8.56 & 31.42 & 96.22 & 1.14 & 72.5 \\
\hline KS4 & $\mathrm{CS}$ & Alfalfa & 0.35 & 2.23 & 23.74 & 103.24 & 178.2 & 7.65 & 93.38 \\
\hline KS6 & $\mathrm{CS}$ & Barely & 0.28 & 0.18 & 4.57 & 14.39 & 12.34 & 0.47 & 131.6 \\
\hline KS13 & NS & Maize & $<0.01$ & 0.23 & 2.82 & 5.31 & 4.37 & 0.08 & 9.18 \\
\hline KS14 & NS & Beet & 0.02 & 0.28 & 2.06 & 3.9 & 3.95 & 0.11 & 8.7 \\
\hline KS15 & NS & Alfalfa & 0.02 & 0.47 & 4.19 & 13.86 & 10.45 & 0.19 & 15.22 \\
\hline KS16 & NS & Barely & $<0.01$ & 0.05 & 0.23 & 4.13 & 0.52 & 0.02 & 17.23 \\
\hline $\mathrm{FAO} / \mathrm{WHO}$ & & & 0.1 & 50 & 2.3 & 73 & 67 & 0.3 & 100 \\
\hline
\end{tabular}

CS contaminated samples (grown on sewage-irrigated soils), NS non-contaminated samples (well-irrigated soils)

The last row is the maximum permissible limit of crops defined by the FAO/WHO [15]
Table 5 The calculated transfer factor (TF) of heavy metals for different plants of the studied area

\begin{tabular}{llllllllll}
\hline Sample no. & ID & Plant & $\mathrm{Cd}$ & $\mathrm{Co}$ & $\mathrm{Cr}$ & $\mathrm{Cu}$ & $\mathrm{Ni}$ & $\mathrm{Pb}$ & $\mathrm{Zn}$ \\
\hline KS3 & CS & Maize & 0.03 & 0.03 & 0.01 & 0.43 & 0.14 & 0.25 & 0.36 \\
KS5 & CS & Beet & 0.04 & 0.02 & 0.01 & 0.30 & 0.12 & 0.05 & 0.31 \\
KS4 & CS & Alfalfa & 0.09 & 0.02 & 0.03 & 0.97 & 0.22 & 0.36 & 0.41 \\
KS6 & CS & Barely & 0.06 & 0.00 & 0.00 & 0.15 & 0.01 & 0.02 & 0.61 \\
KS13 & NS & Maize & - & 0.00 & 0.00 & 0.34 & 0.01 & 0.01 & 0.18 \\
KS14 & NS & Beet & 0.02 & 0.01 & 0.00 & 0.32 & 0.01 & 0.02 & 0.14 \\
KS15 & NS & Alfalfa & 0.03 & 0.01 & 0.01 & 1.05 & 0.02 & 0.03 & 0.23 \\
KS16 & NS & Barely & - & 0.00 & 0.00 & 0.41 & 0.00 & 0.00 & 0.29 \\
\hline
\end{tabular}

unavailable because its bioavailability is less than $1 \%$ in unpolluted samples and does not exceed $2 \%$ in the polluted soils (Fig. 8). As a whole, background samples have low heavy metal bioavailability with maximum values of $\mathrm{Zn}$ (mean 28\%) followed by $\mathrm{Pb}, \mathrm{Cu}$ and $\mathrm{Cd}$. The bioavailable content of heavy metals in non-polluted agricultural soils is the same or slightly higher than that in background samples, while the bioavailable values of heavy metals become extremely high in the polluted soils, so that $\mathrm{Pb}, \mathrm{Cd}$ and $\mathrm{Zn}$ show $>50 \%$ bioavailability (Fig. 8 ). This means that agricultural activities alone have no effect on the amount of bioavailability, but irrigation with sewage has been an effective factor in increasing bioavailability.

\subsection{Heavy metal concentration of plants}

The heavy metal concentration of analyzed plants is shown in Table 4. The heavy metal contents of edible parts change dramatically among various plants and different elements. All plants cultivated in sewage-irrigated soils accumulate higher heavy metals in comparison with control samples. The $\mathrm{Cd}$ concentrations of the control samples are very low ( $\leq 0.02 \mathrm{mg} \mathrm{kg}^{-1}$ ), while polluted plants have Cd concentrations higher than $0.12 \mathrm{mg} \mathrm{kg}^{-1} \mathrm{Cd}$ (Table 4). In the plants of polluted soils, although the amount of Co concentration in maize, beet and alfalfa is similar (2.16-2.86 mg kg$\left.{ }^{-1}\right)$, barely has a significantly lower Co concentration. The highest content of $\mathrm{Cr}$ is accumulated in alfalfa, and the lowest value is obtained from barley (Table 4). The control plants have low $\mathrm{Cu}$ and $\mathrm{Ni}$ concentrations (less than $14 \mathrm{mg} \mathrm{kg}^{-1}$ and $11 \mathrm{mg} \mathrm{kg}^{-1}$, respectively), while polluted samples contain elevated values of these metals over $100 \mathrm{mg} \mathrm{kg}^{-1}$ alfalfa for $\mathrm{Cu}$ and maize and alfalfa for $\mathrm{Ni}$ (Table 4). The $\mathrm{Pb}$ concentration in polluted plants exceeds $5 \mathrm{mg} \mathrm{kg}^{-1}$ in alfalfa and maize samples which are cultivated in sewageirrigated soils. The concentration of $\mathrm{Zn}$ in barely, unlike the other heavy metals, shows the highest values, so that polluted sample releases $131.6 \mathrm{mg} \mathrm{kg}^{-1} \mathrm{Zn}$ (Table 4). The concentrations of $\mathrm{Cd}, \mathrm{Cr}, \mathrm{Ni}$ and $\mathrm{Pb}$ in all plants cultivated on the polluted soils exceed the maximum permissible limit of crops [15, 36] (Table 4). The Co concentrations are below the permissible limit, and alfalfa and barely have a higher concentration of $\mathrm{Cu}$ and $\mathrm{Zn}$ than the permissible limit, respectively. However, as mentioned before, the plants cultivated in the studied area would not be consumed by humans. The permissible limit legislations are not comprehensive for animal feeds and do not include all heavy metals. The maximum standard concentrations have been determined as $0.5,10,35$ and $5 \mathrm{mg} \mathrm{kg}^{-1}$ for $\mathrm{Cd}, \mathrm{Cr}, \mathrm{Cu}$ and $\mathrm{Pb}$, respectively, for animal feed in China 

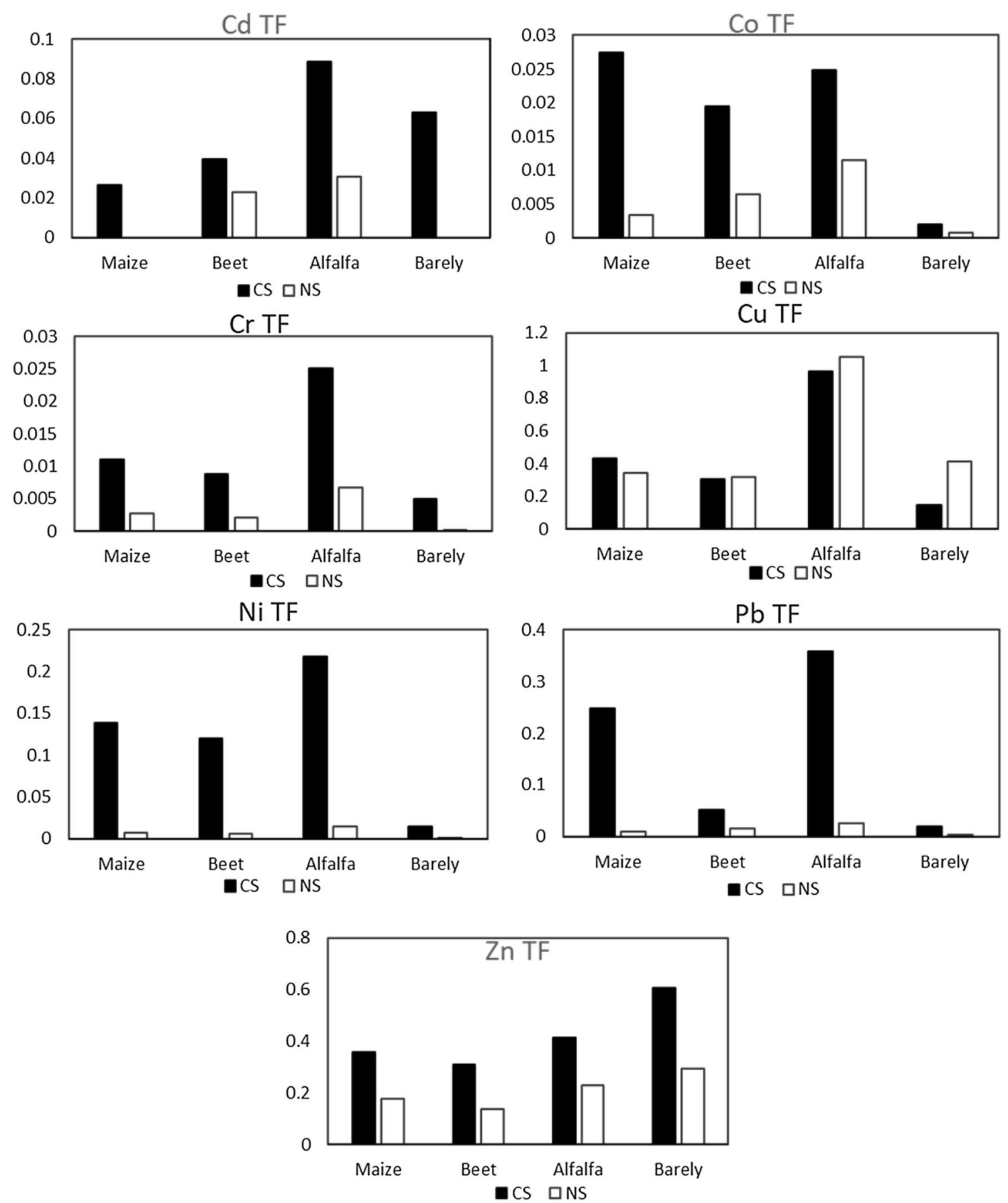

Fig. 9 Different transfer factor (TF) values of heavy metals for plants grown on the polluted (CS) and un-contaminated (NS) soils

Table 6 The calculated enrichment factor (EF) of heavy metals in plants cultivated on the sewage-irrigated soils

\begin{tabular}{llllllrl}
\hline Plant & $\mathrm{Cd}$ & $\mathrm{Co}$ & $\mathrm{Cr}$ & $\mathrm{Cu}$ & $\mathrm{Ni}$ & $\mathrm{Pb}$ & $\mathrm{Zn}$ \\
\hline Maize & - & 7.99 & 4.06 & 1.27 & 19.36 & 26.55 & 2.01 \\
Beet & 1.71 & 3.02 & 4.32 & 0.96 & 22.81 & 3.29 & 2.23 \\
Alfalfa & 2.89 & 2.16 & 3.76 & 0.92 & 14.48 & 14.01 & 1.79 \\
Barely & - & 2.36 & 19.73 & 0.36 & 20.80 & 7.59 & 2.08 \\
\hline
\end{tabular}




\section{Enrichment Factor}

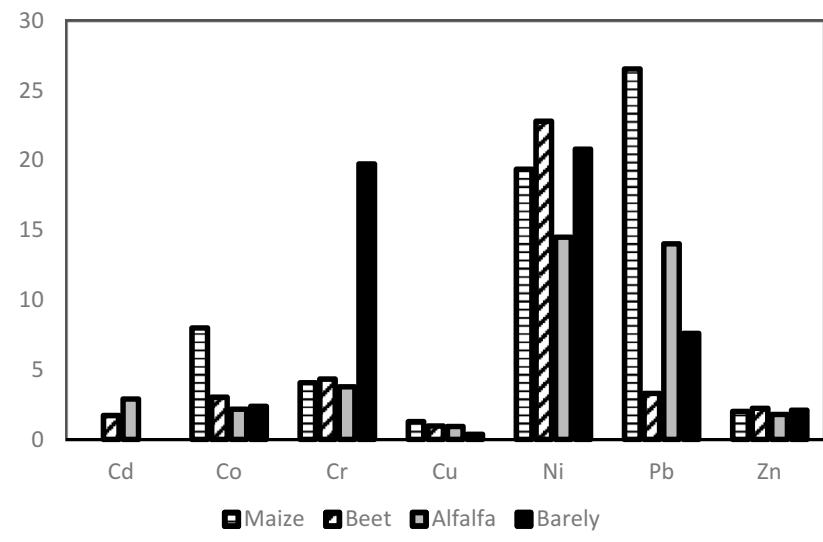

Fig. 10 The calculated enrichment factor (EF) of heavy metals in sewage-irrigated plants of SR

[47]. In comparison with this standard, polluted alfalfa and maize have a higher concentration of $\mathrm{Cr}, \mathrm{Cu}$ and $\mathrm{Pb}$ than permissible limits.

\subsection{Transfer factor (TF) and enrichment factors (EF) of heavy metals}

The resulted TF values are presented in Table 5. The main reasons for variations in transfer factors among different plants are various concentrations of elements in soils and differences in element uptake by every plant $[2,11]$. The TF is a principal factor in controlling environmental risks to consumers (animals or humans) for any specific plant or metal $[20,46]$. Generally, the contaminated plants have higher TF than the control samples (Fig. 9). High TF values indicate relatively poor retention in soils or reflect better efficiency of plants to absorb the element, and in turn, low TFs represent the intense sorption of the element to the soil colloids [5]. Similar to SR, high content of heavy metal in soils and elevated TF values of plants were reported in other sewage-irrigated areas (e.g., [8, 17, 46, 48]).

From Table 6, it is understood that all heavy metals except $\mathrm{Cu}$ show high enrichment in the plants grown on the sewage-irrigated soils. For example, the EF is very high for $\mathrm{Ni}$ and $\mathrm{Pb}$ in maize and alfalfa, for $\mathrm{Ni}$ in beet, and for $\mathrm{Ni}$ and $\mathrm{Cr}$ in barely (Fig. 10).

\section{Conclusion}

Long-term sewage irrigation induced distinctive geochemical changes in the soils to the south of Sabzevar, NE of Iran. These soils have been intensely enriched in many heavy metals, HFSE and REE compared to background samples. The wastewater irrigation has led to a decrease in $\mathrm{pH}$ and increase in TOC in soils, which in turn enhanced heavy metal bioavailability. The concentration of heavy metals in plants that were cultivated on the sewage-irrigated soils is significantly higher than control samples. The calculated TF and EF indexes indicate that heavy metal adsorption in plants that grow in polluted soils is considerably higher than that in other samples. Although animal feed plants are allowed to cultivate in sewage-irrigated areas, the concentration of heavy metals such as $\mathrm{Cr}$, $\mathrm{Cu}$ and $\mathrm{Pb}$ in some plants such as alfalfa and maize is higher than all standard levels determined for crops or animal feed. Therefore, it is necessary to keep regular monitoring of toxic elements in the sewage-irrigated soils and plants and reconsider environmental rules that permit animal feed crops in the intensely polluted areas such as the studied area.

Acknowledgements Some analytical cost of this Project was funded by Payame Noor University (Grant No. 518407). Authors would like to thank two anonymous referees who provided valuable suggestions for improving the quality of the paper.

\section{Compliance with ethical standards}

Conflict of interest The authors declare that they have no conflict of interest.

\section{References}

1. Ahmad MK, Islam S, Rahman S, Haque MR, Islam MM (2010) Heavy metals is water, sediment and some fishes of Buringanga River Bangladesh. Int J Environ Res 4(2):321-332

2. Ahmad K, Khan Zl, Yasmin S et al (2016) Contamination of soil and carrots irrigated with different sources of water in Punjab Pakistan. Environ Earth Sci 75:426. https://doi.org/10.1007/ s12665-016-5348-4

3. Alaminia Z, Karimpour MH, Homam SM, Finger F (2013) The magmatic record in the Arghash region (northeast Iran) and tectonic implications. Int J Earth Sci Geol Rundsch 102:1603-1625

4. Alexander EB (2004) Serpentine soil redness, differences among peridotite and serpentinite materials, Klamath Mountains California. Int Geol Rev 46(8):754-764

5. Alloway BJ, Ayres CD (1997) Chemical principles of environmental pollution, 2nd edn. Blackie Academic and Professional, London

6. Baroz R, Macaudiere J, Montigny R, Noghreyan H, Ohnenstetter M, Rocci G (1984) Ophiolites and related formations in the central part of the Sabzevar range (Iran) and possible geotectonic reconstructions. Neues J Geol Paläontol Abh 168:358-388

7. Bower CA, Hatcher JT (1966) Simultaneous determination of surface area and cation-exchange capacity. Soil Sci Soc Am Pro 30:525-527

8. Chary NS, Kamala CT, Raj DSS (2008) Assessing risk of heavy metals from consuming food grown on sewage irrigated soils and food chain transfer. Ecotoxicol Tox Environ Safe 69:513-524 
9. Chopra AK, Pathak C (2012) Bioaccumulation and translocation efficiency of heavy metals in vegetables grown on long-term wastewater irrigated soil near Bindal River Dehradun. Agric Res 1(2):157-164

10. Cicek A, Karaman MR, Turan M, Gunes A, Cigdem A (2013) Yield and nutrient status of wheat plant (T. aestivum) influenced by municipal wastewater irrigation. J Food Agric Environ 11:733-737

11. Cui YJ, Zhu YG, Zhai RH (2004) Transfer of metals from near a smelter in Nanning, China. Environ Int 30:785-791

12. Davranche $M$, Grybos $M$, Gruau G, Pédrot M, Dia A, Marsac $R$ (2011) Rare earth element patterns: a tool for identifying trace metal sources during wetland soil reduction. Chem Geol 284:127-137

13. Dolan R, Van Loon J, Templeton D et al (1990) Assessment of ICP-MS for routine multielement analysis of soil samples in environmental trace element studies. Fresenius J Anal Chem 336:99-105. https://doi.org/10.1007/BF00322545

14. Esmaeili A, Moore F, Keshavarzi B, Jaafarzadeh N, Kermani M (2014) A geochemical survey of heavy metals in agricultural and background soils of the Isfahan industrial zone Iran. Catena 121:88-98

15. FAO/WHO (2001) Food additives and contaminants. Joint Codex Alimentarius Commission, FAO/WHO Food standards Program, ALINORM 01/12A

16. Hemmat A, Aghilinategh T, Rezainejad Y, Sadeghi M (2010) Long-term impacts of municipal solid waste compost, sewage sludge and farmyard manure application on organic carbon, bulk density and consistency limits of a calcareous soil in central Iran. Soil Till Res 108(1-2):43-50

17. Islam MA, Romić $D$, Akber MA, Romić M (2018) Trace metals accumulation in soil irrigated with polluted water and assessment of human health risk from vegetable consumption in Bangladesh. Environ Geochem Health 40:59-85

18. Jalali M, Merikhpour H, Kaledhonkar MJ, Van Der Zee S (2008) Effects of wastewater irrigation on soil sodicity and nutrient leaching in calcareous soils. Agric Water Manag 95(2):143-153

19. Jamshidi K, Ghasemi H, Sadeghian M (2014) Petrology and geochemistry of the Sabzevar post-ophiolitic high silica adakitic rocks. Petrology 5:51-68 (in Persian)

20. Kabata-Pendias A, Pendias H (1992) Trace elements in soil and plants, 2nd edn. CRC, Boca Raton

21. Kashem MA, Singh BR, Kondo T, Imamul Huq SM, Kawai S (2007) Comparison of extractability of $\mathrm{Cd}, \mathrm{Cu}, \mathrm{Pb}$ and $\mathrm{Zn}$ with sequential extraction in contaminated and non-contaminated soils. Int J Env Sci Technol 4(2):169-176

22. Khalatbari Jafari M, Babaie HA, Gani M (2013) Geochemical evidence for Late Cretaceous marginal arc-to-back arc transition in the Sabzevar ophiolitic extrusive sequence, northeast Iran. J Asian Earth Sci 70-71:209-230

23. Kiziloglu FM, Turan M, Sahin U, Kuslu Y, Dursun A (2008) Effects of untreated and treated wastewater irrigation on some chemical properties of cauliflower (Brassica olerecea L. var. botrytis) and red cabbage (Brassica olerecea L. var. rubra) grown on calcareous soil in Turkey. Agric Water Manag 95:716-724

24. Klay S, Charef A, Ayed L, Houman B, Rezgui F (2010) Effect of irrigation with treated wastewater on geochemical properties (saltiness, C, N and heavy metals) of isohumic soils (Zaouit Sousse perimeter, Oriental Tunisia). Desalination 253:180-187

25. Laveuf C, Cornu S (2009) A review on the potentiality of rare earth elements to trace pedogenetic processes. Geoderma 154:1-12

26. Lindsay WL, Norvell WA (1978) Development of a DTPA soil test for zinc, iron, manganese, and copper. Soil Sci Soc Am J 42(3):421-428
27. Mazhari SA, Mazloumi Bajestani AR, Sharifian Attar R (2013) Geochemical investigation of Davarzan surface soils, West of Sabzevar, NE Iran. Iran J Earth Sci 5:43-53

28. Mazhari SA, Sharifian Attar R (2015) Rare earth elements in surface soils of the Davarzan area, NE of Iran. Geod Reg 5:25-33

29. Mazhari SA (2016) Petrogenesis of adakite and high-Nb basalt association in the SW of Sabzevar Zone NE of Iran: evidence for slab melt-mantle interaction. J Afr Earth Sci 116:170-181

30. Mazhari SA, Sharifian R, Haghighi F (2017) Heavy metals concentration and availability of different soils in Sabzevar area, NE of Iran. J Afr Earth Sci 134:106-112

31. Mazhari SA, Mazloumi Bajestani AR, Hateffi F, Aliabadi K, Haghigh F (2018) Soil geochemistry as a tool for the origin investigation and environmental evaluation of urban parks in Mashhad city NE of Iran. Environ Earth Sci 77:492. https:// doi.org/10.1007/s12665-018-7684-z

32. McBride MB (1989) Reactions controlling heavy metal solubility in soils. Adv Soil Sci 10:1-56

33. Moghadam HS, Kheder M, Arai S, Stern R, Ghorbani G, Tamura A, Ottley $\mathrm{CH}$ (2015) Arc-related harzburgite-dunite-chromitite complexes in the mantle section of the Sabzevar ophiolite, Iran: a model for formation of podiform chromitites. Gondwana Res 27:575-593. https://doi.org/10.1016/j. gr.2013.09.007

34. Nabavi MH (1976) Introduction to geology of Iran. Geological Survey of Iran press, Tehran (in Persian)

35. Quantin C, Ettler V, Garnier J, Sebec O (2008) Sources and extractability of chromium and nickel in soil profiles developed on Czech serpentinites. C R Geosci 340:872-882

36. Rahmani J, Fakhri Y, Shahsavani A, Bahmani Z et al (2018) A systematic review and meta analysis of metal concentrations in canned tuna fish in Iran and human health risk assessment. Food Chem Toxicol 118:753-765

37. Rodriguez JA, Nanos N, Grau JM, Gill L, Lopez-Arias M (2008) Multiscale analysis of heavy metal contents in Spanish agricultural topsoils. Chemosphere 70:1085-1096

38. Romic M, Matijevic L, Bakic H, Romic D (2014) Environmental risk assessment of soil contamination. In: Hernandez-Soraino MC (ed) Copper accumulation in vineyard soils: distribution, fractionation and bioavailability assessment. Intech publication, London, pp 800-825. https://doi.org/10.5772/57266

39. Rossetti F, Nasrabadi M, Vignaroli G, Theye T, Gerdes V, Razavi $\mathrm{MH}$, MoinVaziri H (2010) Early Cretaceous migmatitic mafic granulites from the Sabzevar range (NE Iran): implications for the closure of the Mesozoic peri-Tethyan oceans in central Iran. Terra Nova 22:26-34

40. Rossetti F, Nasrabadi $M$, Theye $T$, Gerdes $A$, Monié $P$, Lucci $F$, Vignaroli G (2014) Adakite differentiation and emplacement in a subduction channel: the late Paleocene Sabzevar magmatism (NE Iran). Geol Soc Am Bull 3-4:317-343

41. Sahandi MR, Tavousian S, Zohrebakhsh A (1992) 1:250000 geological map of Sabzevar. Geological Survey of Iran Press, Tehran

42. Shojaei S, Zehtabian GR, Jafari M, Khosravi H (2017) Evaluating the application of wastewater in different soil depths (Case study: Zabol). Pollution 3(1):113-121

43. Singh J, Suraj KU, Rajaneesh KP, Gupta V (2011) Accumulation of heavy metals in soil and paddy crop (Oryza sativa) irrigated with water of Ramgarh Lake, Gorakhpur, UP India. Toxicol Environ Chem 93(3):462-473

44. Solgi E, Sheikhzadeh $H$, Solgi M (2018) Role of irrigation water, inorganic and organic fertilizers in soil and crop contamination by potentially hazardous elements in intensive farming systems: case study from Moghan agro-industry Iran. J Geochem Explor 185:74-80

45. Sun SS, McDonough WF (1989) Chemical and isotopic systematics of the oceanic basalts: implications for mantle composition 
and processes. In: Saunders AD, Norry MJ (eds) Magmatism in the Oceanic Basalts. Geological Society of London, London, pp 313-345

46. Verma P, Agrawal M, Sagar R (2015) Assessment of potential health risks due to heavy metals through vegetable consumption in a tropical area irrigated by treated wastewater. Environ Syst Decis 35:375-388

47. Wang W, Zhang W, Wang X, Lei C, Tang R, Zhang F, Yang Q, Zhu $F$ (2017) Tracing heavy metals in 'swine manure-maggot-chicken' production chain. Sci Rep 7:8417. https://doi. org/10.1038/s41598-017-07317-2
48. Xue ZJ, Liu SQ, Liu YL, Yan YL (2012) Health risk assessment of heavy metals for edible parts of vegetables grown in sewageirrigated soils in suburbs of Baoding City, China. Environ Monit Assess 184:3503-3513

Publisher's Note Springer Nature remains neutral with regard to jurisdictional claims in published maps and institutional affiliations. 